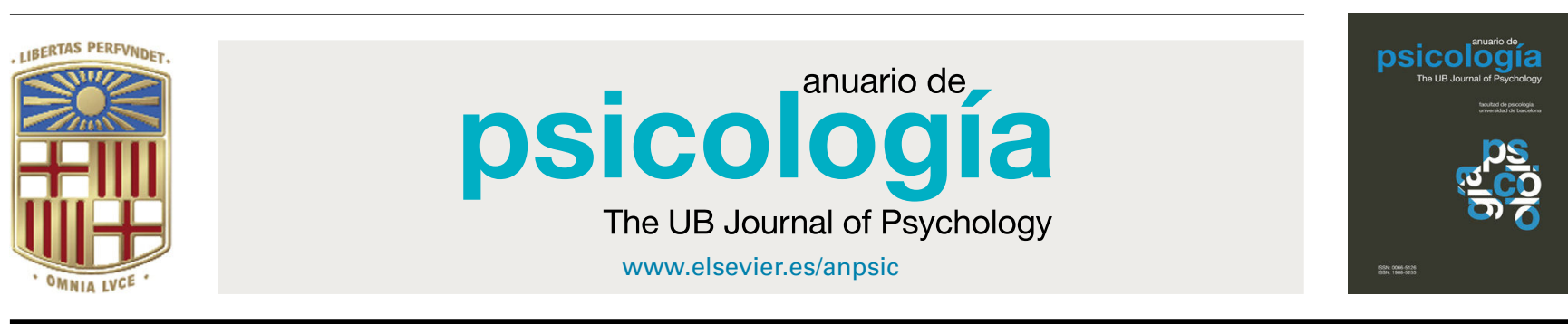

ORIGINAL RESEARCH PAPER

\title{
Consistent individual differences in some behaviors in mice of the C57Bl/6J inbred strain
}

\section{José Vidal-Gómez}

Universitat de Barcelona, Spain

Received 6 April 2016; accepted 27 June 2016

Available online 19 September 2016

\section{KEYWORDS}

Consistent behavior; Open-field; C57Bl/6; Ambulation; Rearing

\section{PALABRAS CLAVE}

Conducta

consistente;

Campo abierto;

C57Bl/6;

Deambulación;

Incorporación
Abstract Mice of the inbred C57Bl/6J strain displayed considerable inter-mice variation in ambulation, rearing, grooming, and defecation in the open-field (coefficients of variation from $30 \%$ to $150 \%$ ). Those differences were not random, because six measurements of the same behavior, taken along six months, were correlated (Kendall coefficients of concordance were in the range $0.37-0.59$ and statistically significant); yet, the mice displayed different behavioral profiles along the six measurements (i.e. uniqueness occurred within some order). Of all the behaviors measured, only ambulation and rearing were correlated; i.e., they may constitute a behavioral syndrome.

(c) 2016 Universitat de Barcelona. Published by Elsevier España, S.L.U. All rights reserved.

\section{Diferencias individuales consistentes en algunas conductas entre los ratones de la cepa consanguínea $\mathrm{C} 57 \mathrm{BI} / 6 \mathrm{~J}$}

Resumen Los ratones de la cepa consanguínea C57BL/6J muestran una considerable variación entre ellos en las conductas de deambulación, incorporación, aseo, y defecación en el campo abierto (coeficientes de variación entre 30\% y 150\%). Estas diferencias individuales no son aleatorias, porque 6 medidas de la misma conducta, tomadas a lo largo de 6 meses, estaban correlacionadas (los coeficientes de concordancia de Kendall fueron estadísticamente significativos y en el intervalo $0,37-0,59$ ); no obstante, los ratones mostraron perfiles conductuales diferentes a lo largo de las 6 medidas (es decir, la individualidad existía dentro de cierto orden). Entre todas las conductas medidas, solo deambulación e incorporación correlacionaban entre sí; es decir, podrían formar un síndrome conductual.

(c) 2016 Universitat de Barcelona. Publicado por Elsevier España, S.L.U. Todos los derechos reservados. 
Rodents of an inbred strain display large variations in several behaviors: sucrose preference (Strekalova \& Steinbusch, 2010), fear conditioning (Siegmund, Kaltwasser, Holsboer, Czisch, \& Wotjak, 2009), decrease in social interaction after social defeat (Krishnan et al., 2007), ambulation in the open-field and the elevated plus-maze (Vidal, 2015). This variability is not readily explained by genetics or environment, and has been termed intangible variation, developmental noise (Blewitt, Chong, \& Whitelaw, 2004; Falconer, 1989) or third component (Gärtner, 1990).

Some next questions are (a) is that variability temporary or long-lasting? and (b) if the variability is long-lasting, is the variability random or organized? i.e., are high scoring mice in the first measurement also high scoring mice in successive measurements? (and, conversely, are low scorers in the first measurement also low scorers in successive measurements?); this finding would prove the occurrence of consistent individual differences among the animals of an inbred strain. One of the goals of this report is to answer questions (a) and (b) above.

A set of correlated behaviors (behavioral syndromes; Sih, Bell, \& Johnson, 2004) may represent temperament traits in animals (Lewejohann, Zipser, \& Sachser, 2011). Therefore, another goal of this report is to discover behavioral syndromes among the behaviors of inbred C57Bl/6J mice in the open-field.

\section{Method}

\section{Subjects}

Male and female mice of the C57Bl/6J strain were purchased from Harlan Iberica (Barcelona, Spain). Four C57Bl/6J females were mated with four C57BI/6J males, and the offspring were the subjects of this experiment. The males were removed from the females one week before parturition.

Adult mice of the same sex were housed 2-5 per cage, at $21 \pm 1{ }^{\circ} \mathrm{C}$, under a $12 \mathrm{~h}$ light-dark cycle (lights on at 8:00 h). Food and water were available ad libitum. At the time of the first test, the mice were approximately 8 weeks old. The illumination on the floor of the mouse room was 238 lux approximately whereas the illumination on top of one cage was about 108 lux.

The experimental procedures were approved by the University of Barcelona Ethics Committee on Animal Experimentation.

\section{Open field}

The open field was a square enclosure made of gray plastic, $100.0 \mathrm{~cm} \times 100.0 \mathrm{~cm} \times 30.0 \mathrm{~cm}$. An inner, a middle, and an outer zone were defined: the inner zone was a $(40 \mathrm{~cm} \times 40 \mathrm{~cm})$ square situated at $30 \mathrm{~cm}$ from each wall, the middle zone was a $(90 \mathrm{~cm} \times 90 \mathrm{~cm})$ square minus the inner zone, and the outer zone was a $5-\mathrm{cm}$-wide strip along the walls of the open-field. Fig. 1 shows the zones in the openfield. The apparatus was lit by a neon tube that yielded about 190 lux in the center of the field. The open-field test was performed in silence.

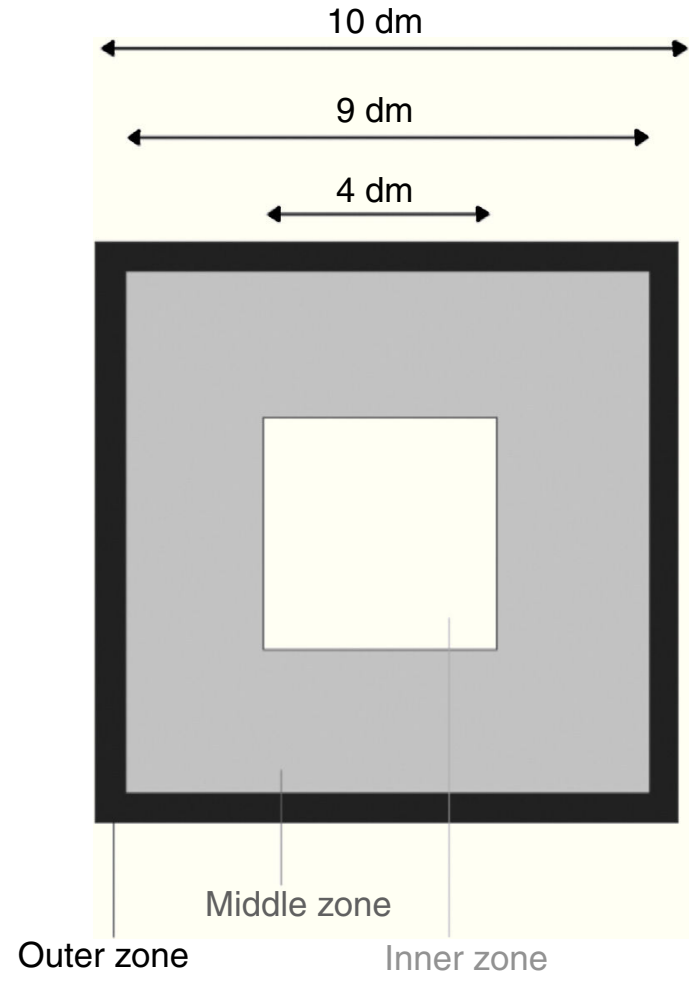

Figure 1 Zones in the open-field.

\section{Procedure}

Mice took the first behavioral test when they were about 8 weeks old. Each mouse was placed in a corner of the openfield and allowed to move freely for $5 \mathrm{~min}$. A video tracking system (Any-maze v. 4.99; Stoelting Co., IL, USA) recorded ambulation (meters) in each zone; besides, these behaviors were scored manually: number of full-stretch rearings (i.e., the erect mouse stands on its rear paws), number of grooming episodes (i.e., the mouse stands on its rear paws and scratches its face with its forepaws), and number of fecal boli. All the trials took place between 15:00 and 19:00 h. The field was washed with disinfectant soap between two mouse sessions.

The mice took five more open-field tests at approximately monthly intervals; the age (days) at the time of each test was 56, 82, 111, 147, 173, 203.

\section{Statistical analysis}

Prior to any analysis, each variable was standardized (that is, converted to $z$ scores, with mean of 0 and standard deviation of 1); standardization was performed in each of the six measurements to estimate the position of each mouse in the group.

Pearson correlation coefficient was used to calculate the correlation matrix corresponding to the six measurements of the same behavior (after standardization of the raw scores). Before computing the correlation coefficients, scatterplots of the appropriate variables were produced: the shapes of the plots were either amorphous or suggested a straight line. 
Table 1 Variability (coefficient of variation) of some variables in the first trial.

\begin{tabular}{lcc}
\hline Variable & Male mice & Female mice \\
\hline amb outer OF & 60 & 40 \\
amb middle OF & 44 & 30 \\
Rear & 38 & 30 \\
Grooming & 79 & 53 \\
Defecation & 264 & 156 \\
\hline
\end{tabular}

Note. Variables: amb outer OF, ambulation in the outer zone of the open-field; $a m b$ middle OF, ambulation in the middle zone of the open-field; rear, number of rearing episodes; grooming, number of grooming episodes; defecation, number of fecal boli. Numbers indicate coefficient of variation (\%). Number of mice: 7 males and 18 females.

Kendall's coefficient of concordance was used to estimate the consistency of any behavior in the six measurements thereof; e.g., if the more active, or less active, mice in a given measurement were also the more active, or less active, mice in the other measurements. Before calculating Kendall's coefficient of concordance, the standardized matrix was transposed; i.e., the measurements (cases) estimated the relative position of the mice (variables).

Groups of mice displaying comparable behavioral profiles were disclosed by sequential cluster analysis (Guertin, 1966; Skinner, 1978): a first cluster analysis selected groups or mice with profiles of similar shape, whereas a second cluster analysis on each of the ensuing groups selected profiles according to elevation (elevation being the mean of the six measurements of a given behavior for each mouse). For the first cluster analysis, the distance used was 1 minus the correlation coefficient; for the second cluster analysis, the distance was elevation (Skinner, 1978); the amalgamation rule was always Ward's method.

The statistical package STATISTICA v.12 (Tulsa, Oklahoma) was used to perform the statistical analyses and to produce the graphs.

\section{Results}

\section{Variability of measurements}

Table 1 shows the coefficients of variation of some variables recorded in the first trial: variability was considerable, with most coefficients of variation being larger than $29 \%$, and some were larger than $100 \%$.

\section{Behavioral change with time}

Fig. 2 shows the score change of the measured behaviors along the six trials: ambulation and rearing decreased steadily and, by the sixth trial, some mice scored zero: for instance, $57 \%$ of male mice and $38 \%$ of female mice did not enter the mid zone; $71 \%$ of male mice and $28 \%$ of female mice did not rear; $100 \%$ of males, and $83 \%$ of females, did not enter the inner zone; because of this, ambulation in the inner open-field was dropped from the analysis.
Table 2 Kendall coefficients of concordance.

\begin{tabular}{llllll}
\hline Variable & \multicolumn{2}{c}{ Male mice } & & \multicolumn{2}{c}{ Female mice } \\
\cline { 2 - 3 } & $W$ & & $p$ & & $p$ \\
\hline amb outer OF & 0.43 & 0.016 & & 0.43 & 0.0003 \\
amb middle OF & 0.47 & 0.009 & & 0.54 & 0.00001 \\
Rear & 0.59 & 0.002 & & 0.46 & 0.0001 \\
Grooming & 0.25 & 0.169 & & 0.37 & 0.0023 \\
Defecation & 0.30 & 0.093 & & 0.26 & 0.065 \\
\hline
\end{tabular}

Note. W, Kendall coefficient of concordance; $p$, statistical probability of W. Variables: amb outer OF, ambulation in the outer zone of the open-field; $a m b$ middle OF, ambulation in the middle zone of the open-field; rear, number of rearing episodes; grooming, number of grooming episodes; defecation, number of fecal boli. Number of mice, 7 males and 18 females.

\section{Consistency of measurements}

Table 2 shows Kendall's coefficient of concordance for the behaviors: ambulation and rearing were consistent (because they displayed relatively high and significant coefficients), whereas grooming and defecation were less consistent (because their coefficients of concordance were low and did not reach statistical significance).

\section{Groups of mice with comparable behavioral profile}

Sequential clustering (as described in the Statistical analysis section) yielded these groups of mice (the mice in each group displaying comparable profiles):

* in male mice (Fig. 3), (a) for ambulation in the outer open-field, these groups emerged: two groups of 2 mice, and 3 mice remained isolated (i.e. those 3 mice had unique profiles); (b) for ambulation in the mid-open-field, all the mice remained isolated; (c) for rearing, these groups emerged: two groups of 2 mice, and 3 mice remained isolated.

* in female mice (Fig. 4), (a) for ambulation in the outer open-field, these groups emerged: three groups of 3 mice, four groups of 2 mice, and 1 mice remained isolated; (b) for ambulation in the mid-open-field, these groups emerged: two groups of 3 mice, four groups of 2 mice, and 4 mice remained isolated; (c) for rearing, these groups emerged: two groups of 3 mice, four groups of 2 mice, and 4 mice remained isolated, (d) for grooming, these groups emerged: one group of 3 mice, four groups of 2 mice, and 7 mice remained isolated.

\section{Correlation between the variables}

The six measurements ( $z$ scores) of each variable were averaged, and the resulting variables were correlated. Table 3 shows the correlation coefficients: (i) ambulation in the outer open-field, ambulation in the mid open-field, and rearing were positively, and significantly, correlated, (ii) ambulation in the inner open-field was significantly correlated only with ambulation in the middle open-field, (iii) grooming and defecation were weakly, and nonsignificantly, correlated with the other variables. 


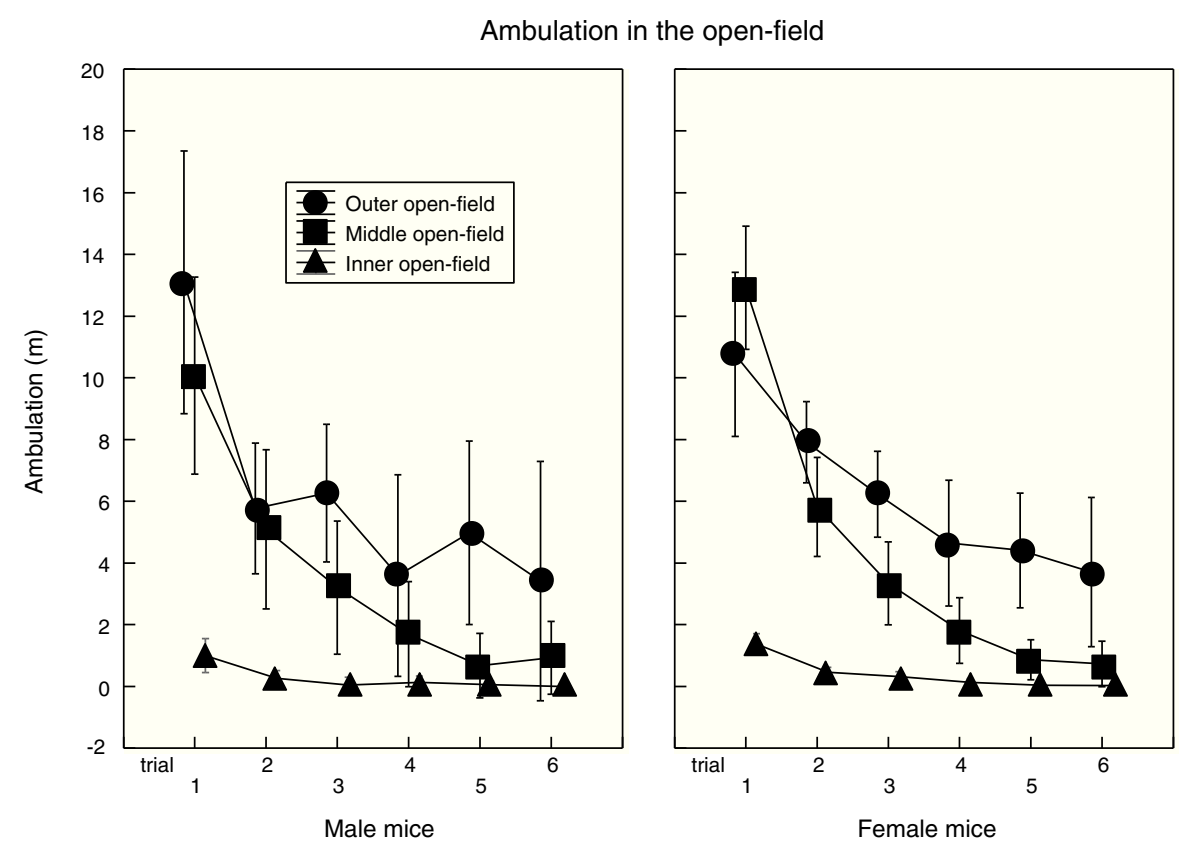

Rearing, grooming and defecation in the open-field
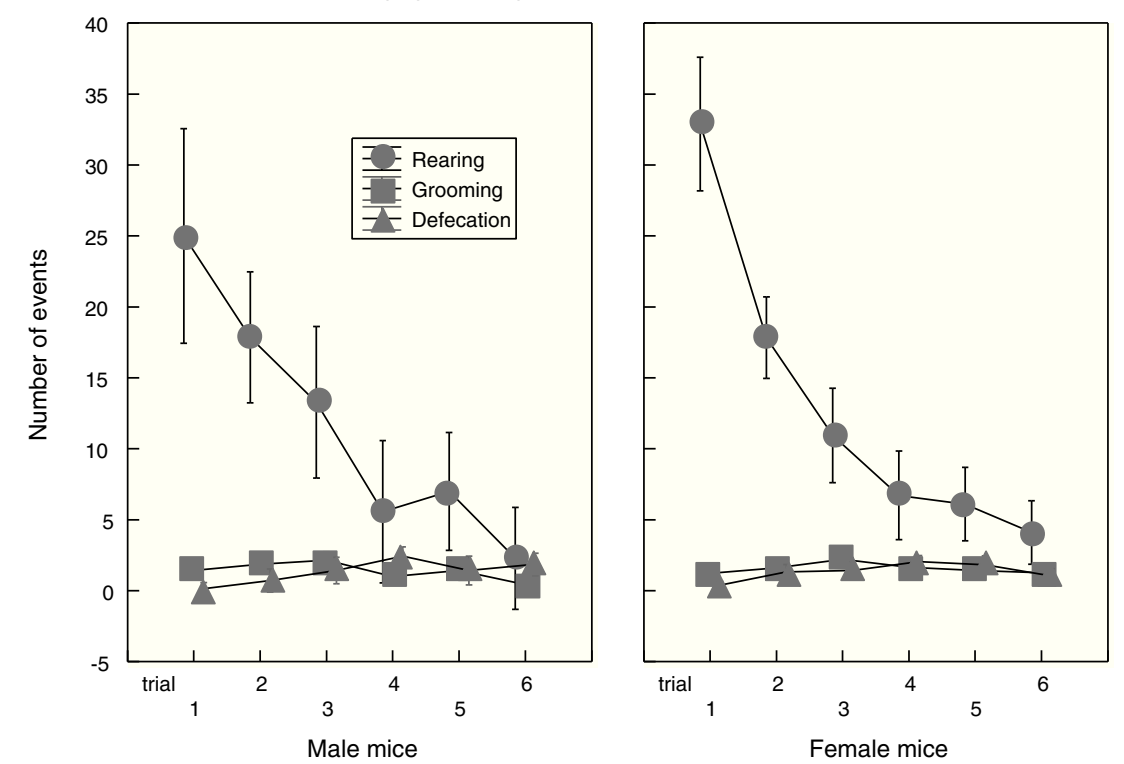

Figure 2 Change of behavioral scores with time. Bars represent $95 \%$ confidence intervals.

Table 3 Correlation coefficients of aggregated variables.

\begin{tabular}{lcccccr}
\hline & amb outer OF & amb midde OF & Rear & Grooming & Defecation & amb inner OF \\
\hline amb outer OF & 1.00 & $0.60^{*}$ & $0.84^{*}$ & 0.33 & -0.10 & 0.20 \\
amb middle OF & $0.60^{*}$ & 1.00 & $0.67^{*}$ & 0.28 & -0.08 & $0.79^{*}$ \\
Rear & $0.84^{*}$ & $0.67^{*}$ & 1.00 & 0.43 & 0.23 & 0.43 \\
Grooming & 0.33 & 0.28 & 0.43 & 1.00 & 0.44 & -0.00 \\
Defecation & -0.10 & -0.08 & 0.23 & 0.44 & 1.00 & 0.00 \\
amb inner OF & 0.20 & $0.79^{*}$ & 0.43 & -0.00 & 0.00 & 1.00 \\
\hline
\end{tabular}

Note. Variables: amb outer OF, ambulation in the outer zone of the open-field; amb middle OF, ambulation in the middle zone of the open-field; rear, number of rearing episodes; grooming, number of grooming episodes; defecation, number of fecal boli; amb inner $O F$, ambulation in the inner open-field (this variable was created by averaging the first three standardized measurements; the other variables were created by averaging the six standardized measurements). Number of mice: 18 females (no males were used). Numbers indicate Pearson correlation coefficient. * $p<0.05$. 

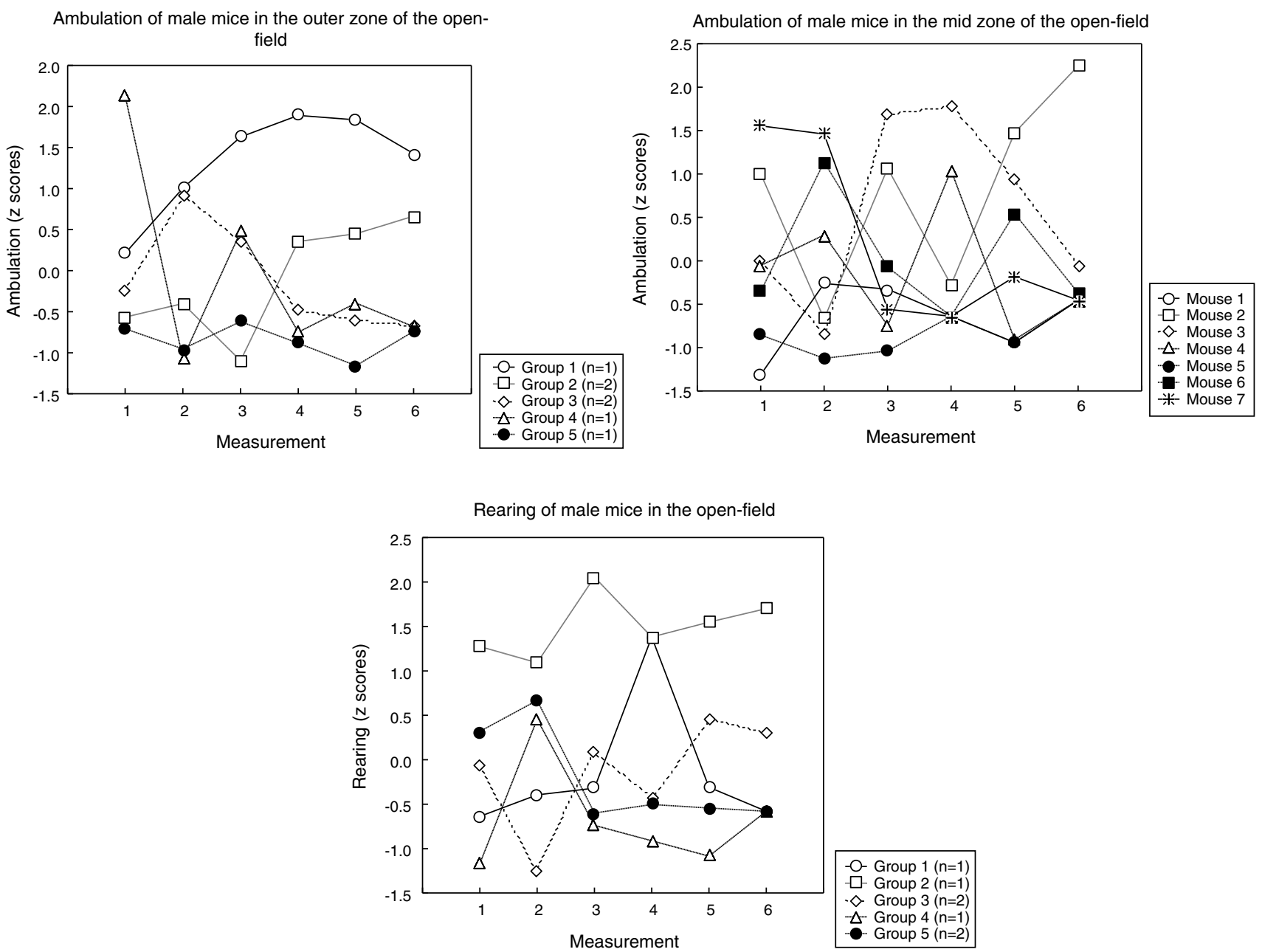

Figure 3 Profiles of homogeneous groups of male mice. Error bars are omitted for clarity.

\section{Discussion}

Results in Fig. 2 confirm a reported finding; i.e., decreased ambulation of $\mathrm{C} 57 \mathrm{Bl} / 6$ mice upon repeated exposure to the same open-field (Bolivar, Caldarone, Reilly, \& Flaherty, 2000; Leussis \& Bolivar, 2006). Yet, the results reported here extend previous results, because exposure to the open-field, in previous studies, took place in a relatively short period in the life of a mouse (one week), whereas the results here spanned six months. In fact, this study could not be extended beyond the sixth measurement, because (i) most of the mice did not enter the inner zone of the open-field, and (ii) a considerable number of mice barely reared or moved (even in the outer openfield).

Data in Table 1 confirm a previous finding, namely that mice of an inbred strain display differences in some behaviors (Krishnan et al., 2007; Siegmund et al., 2009; Strekalova \& Steinbusch, 2010; Vidal, 2015). Nevertheless, the quoted studies left unanswered three questions: (a) are the intermice differences temporary or persistent in the life of the mouse?, (b) do those differences explain a large proportion, or a small proportion, of variance? and (c) if the differences among mice are consistent, is it possible to divide a group of mice into subgroups displaying comparable behavioral profiles?

(a) An answer to this question was provided, up to a point, by Vidal (2015): mice of the C57Bl/6 strain displayed consistent differences in ambulation in the open-field during three months; the present study confirms and extends those findings.

(b) As to the proportion of variability accounted for by those consistent differences, Kendall coefficients of concordance (Table 2) suggest that near $50 \%$ of the maximal order possible occurs in the data matrices (Kendall coefficient of concordance is construed as the proportion of actual rank-order relative to the maximal rank-order; Siegel, 1976).

(c) Figs. 3 and 4 reveal considerable heterogeneity among the mouse profiles; in fact, some of the profiles are unique (i.e., each mouse has its own profile) and the groups of homogeneous profiles are small (2-3 profiles per group). These results were unexpected because the mice were inbred and were bred in essentially the same environment (as a matter of fact, some mice of the same litter had different profiles; not shown). Nevertheless, the mice could be ordered, to some extent, 


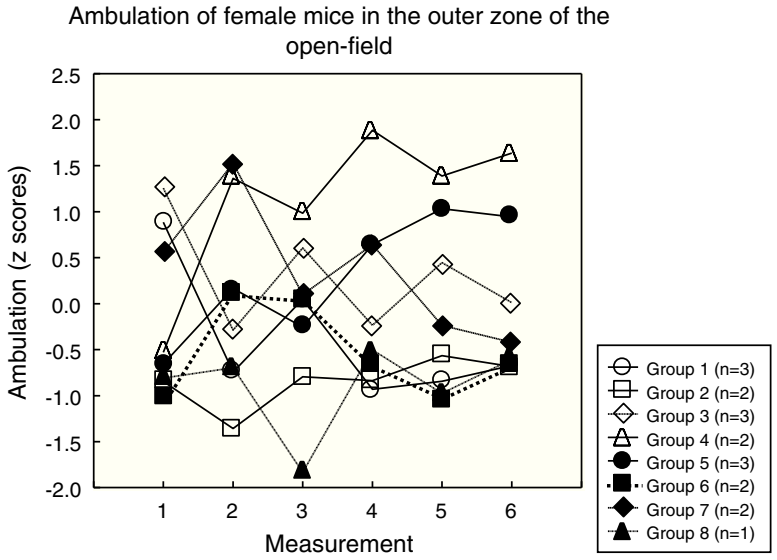

Rearing of female mice in the open-field

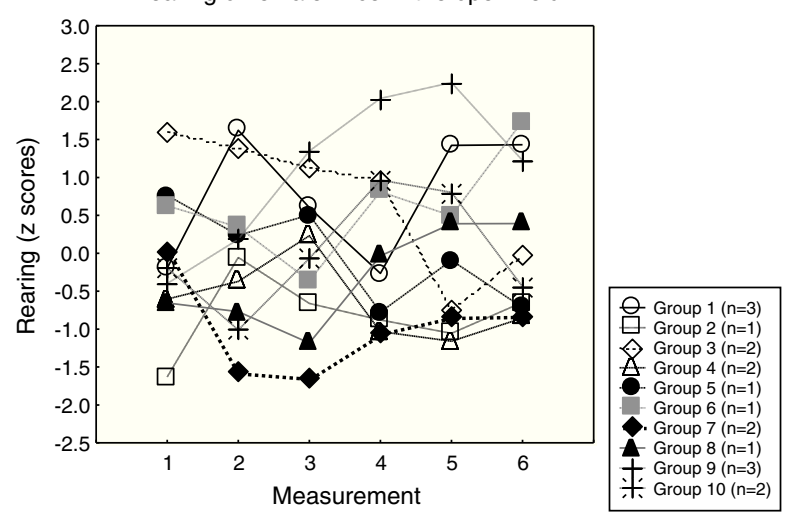

Ambulation of female mice in the middle zone of the open-field

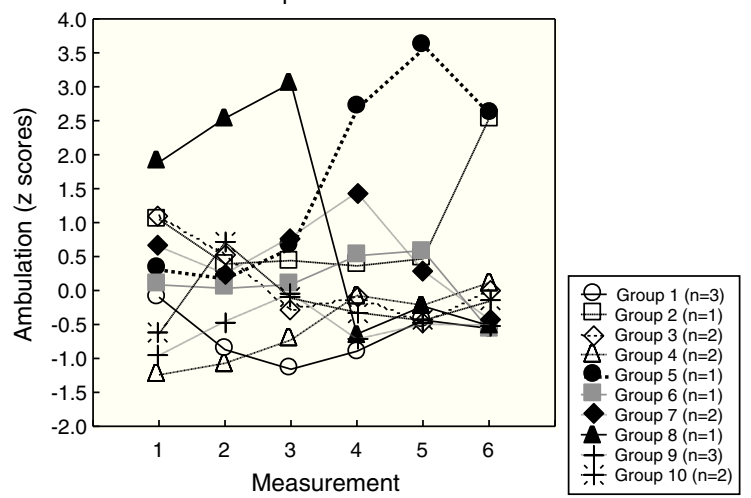

Grooming of female mice in the open-field

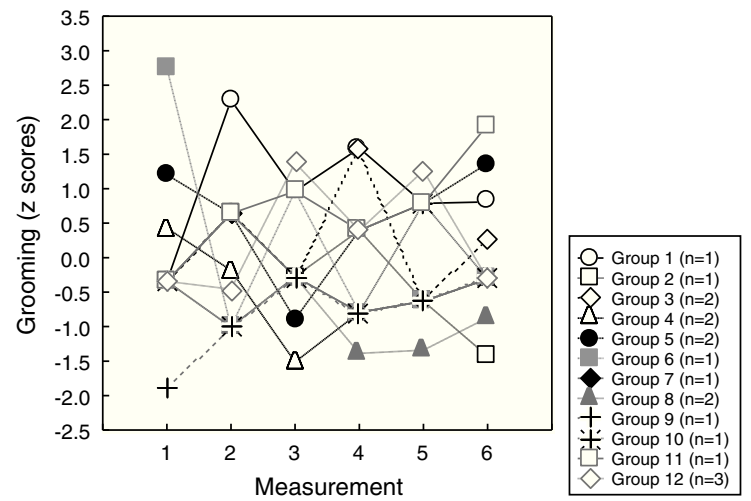

Figure 4 Profiles of homogeneous groups of female mice. Error bars are omitted for clarity.

according to the magnitude of behavior (Table 2): this finding suggests that individual behavior exists within a certain order. This article provides no explanation for the genesis of the individual profiles displayed in Figs. 3 and 4 , but poses the question of the relative contribution of genes and environment to individual differences in behavior.

The coexistence of individuality and order in some behaviors is reminiscent of a similar situation in personality studies: on the one hand, individual profiles of behavior have been found (Mischel \& Shoda, 1995; Smith, Shoda, Cumming, \& Smoll, 2009) but, on the other hand, averaged behavior across time and situations has been favored over individual profiles (Epstein, 1979). The results reported here suggest that both positions are correct.

Another goal of this report was to discover groups of correlated behaviors (behavioral syndromes, Sih et al., 2004). To do this, the six measurements of a given behavior were averaged (Epstein, 1979) and the averaged behaviors were correlated (this procedure was omitted in male mice due to the scarcity of subjects, $n=7$ ). Table 3 reveals a group of correlated behaviors: ambulation in the outer open-field, ambulation in the middle open-field, and rearing. This group may be interpreted as activity in a relatively safe zone of the open-field (Choleris, Thomas, Kavaliers, \& Prato, 2001; Simon, Dupuis, \& Costentin, 1994; Treit \& Fundytus, 1989).
To summarize, inbred mice of the C57Bl/6J strain display both variable behavioral profiles and consistent individual differences in the same behaviors.

\section{References}

Blewitt, M. E., Chong, S., \& Whitelaw, E. (2004). How the mouse got its spots. Trends in Genetics, 20, 550-554.

Bolivar, V. J., Caldarone, B. J., Reilly, A. A., \& Flaherty, L. (2000). Habituation of activity in an open field: A survey of inbred strains and F1 hybrids. Behavior Genetics, 30, 285-293.

Choleris, E., Thomas, A. W., Kavaliers, M., \& Prato, F. S. (2001). A detailed ethological analysis of the mouse open field test: Effects of diazepam, chlordiazepoxide and an extremely low frequency pulsed magnetic field. Neuroscience and Biobehavioral Reviews, 25, 235-260.

Epstein, S. (1979). The stability of behavior: I. On predicting most of the people much of the time. Personality and Social Psychology, 37, 1097-1126.

Falconer, D. S. (1989). Introduction to quantitative genetics. Harlow, UK: Longman Scientific and Technical.

Gärtner, K. (1990). A third component causing random variability beside environment and genotype. A reason for the limited success of a 30 year long effort to standardize laboratory animals? Laboratory Animals, 24, 71-77.

Guertin, W. H. (1966). The search for recurring patterns among individual profiles. Educational and Psychological Measurement, 26, $151-165$ 
Krishnan, V., Han, M.-H., Graham, D. L., Berton, O., Renthal, W., Russo, S. J., \& Nestler, E. J. (2007). Molecular adaptations underlying susceptibility and resistance to social defeat in brain reward regions. Cell, 131, 391-404.

Leussis, M. P., \& Bolivar, V. J. (2006). Habituation in rodents: A review of behavior, neurobiology, and genetics. Neuroscience and Biobehavioral Reviews, 30, 1045-1064.

Lewejohann, L., Zipser, B., \& Sachser, N. (2011). "Personality" in laboratory mice used for biomedical research: A way of understanding variability? Developmental Psychobiology, 53, 624-630.

Mischel, W., \& Shoda, Y. (1995). A cognitive-affective system theory of personality: Reconceptualizing situations, dispositions, dynamics, and invariance in personality structure. Psychological Review, 102, 246-268.

Siegel, S. (1976). Estadística no paramétrica aplicada a las ciencias de la conducta. México, DF: Editorial Trillas.

Siegmund, A., Kaltwasser, S. F., Holsboer, F., Czisch, M., \& Wotjak, C. T. (2009). Hippocampal $\mathrm{N}$-acetylaspartate levels before trauma predict the development of long-lasting posttraumatic stress disorder-like symptoms in mice. Biological Psychiatry, 65, 258-262.
Sih, A., Bell, A., \& Johnson, J. C. (2004). Behavioral syndromes: An ecological and evolutionary overview. Trends in Ecology and Evolution, 19, 372-378.

Simon, P., Dupuis, R., \& Costentin, J. (1994). Thigmotaxis as an index of anxiety in mice. Influence of dopaminergic transmissions. Behavioural Brain Research, 61, 59-64.

Skinner, H. A. (1978). Differentiating the contribution of elevation, scatter and shape in profile similarity. Educational and Psychological Measurement, 38, 297-308.

Smith, R. E., Shoda, Y., Cumming, S. P., \& Smoll, F. L. (2009). Behavioral signatures at the ballpark: Intraindividual consistency of adults' situation - Behavior patterns and their interpersonal consequences. Journal of Research in Personality, 43, 187-195.

Strekalova, T., \& Steinbusch, H. W. M. (2010). Measuring behavior in mice with chronic stress depression paradigm. Progress in NeuroPsychopharmacology \& Biological Psychiatry, 34, 348-361.

Treit, D., \& Fundytus, M. (1989). Thigmotaxis as a test for anxiolytic activity in rats. Pharmachology, Biochemistry and Behavior, 31, 959-962.

Vidal, J. (2015). The third component, or intangible variation, is relatively consistent along time in mice of the C57BL/6J strain. Anuario de Psicologia, 45, 235-247. 